\title{
Multicultural Education Based on North Sumatera Folkloreas a Source of Character Building in Early Childhood
}

\author{
Ratih Baiduri ${ }^{1}$, Leylia Khairani ${ }^{2}$, Puspitawati ${ }^{3}$ \\ \{ratihbaiduri215@gmail.com ${ }^{1}$ \} \\ Department of Anthropology Education, Unimed, Medan, Indonesia ${ }^{1}$, Department of Communication \\ Sciences UMSU, Medan, Indonesia ${ }^{2,3}$
}

\begin{abstract}
Early age is a golden age in child development. Therefore, it is ideal to shape children characteristics by introducing them to various folklores. North Sumatera is known as a source of ethnic diversity as well as the stories of its people. North Sumatera folklore is also a multicultural learning medium that is important for early childhood. This study aims to reveal: (1) the values of character and multicultural education contained in the folklore of North Sumatera; (2) the role of North Sumatera folklore which has been reconstructed as a medium for character building as well as a source of learning for multicultural education. The research design uses qualitative research methods with an ethnographic approach by taking various informants, including early education teachers, traditional leaders who understand North Sumatera folklore and early age experts. Research techniques use interviews, observation, literature studies and documentation. The results of this study are that there are several values of character education. The value of multicultural education that can be embedded in children includes the value of diversity, religious tolerance, mutual respect and being able to work together. The value of the character education that is formed can also play a role as a learning media for multicultural education.
\end{abstract}

Keywords: early age, North Sumatera folklores, character education, multicultural education

\section{Introduction}

Today folklore has rarely been played especially among the younger generation for early childhood. Schools that should be important places to introduce folklore no longer include folklore in the learning curriculum. Likewise, parents have very rarely read or introduced folklore to their children. Folk stories also become less competitive with other polarized stories among the younger generation. The disappearance of folklore in various circles among the younger generation should be the concern of education and cultural experts. Although not all subfields in folklore have the same type as evidence of their impact (Pryor, A and P. Bowman, 2016).

Experts have expressed the importance of schools to become an arena in introducing folklore to students (Hamer, 2000; Altman et al., 1978; Rosenberg, 1990; Nusz, 1994; Bulger, 1991), but the efforts that done by experts do not also make attention focused on making schools an arena learning folklore especially in Indonesia. Early age is a time of 
anxiety in child development, therefore it is ideal to shape the characteristics of children by introducing various folklore.

North Sumatera is known as a source of ethnic diversity as well as the stories of its people. They are should many efforts to introduce North Sumatera folklore. We can introduce folklore for children from early childhood with a story telling as well as a learning media for children to know and understand the ethnic and religious diversity that exists in North Sumatera. By introducing North Sumatera folklore for early childhood will provide a foundation for the formation of good children's character because it contains moral, social and spiritual values.

North Sumatera folklore is also a multicultural learning medium that is important for early childhood. North Sumatera is an area rich in folklore originating from various backgrounds in Indonesia. North Sumatera can be said to be a multicultural area. Various ethnic groups in North Sumatera have stories of their own people. Various folklores originating from North Sumatera can be used as a learning resource for character and multicultural education, especially for early childhood. Although we realize that almost all folklore is inseparable from the content of mystical or magical elements, some forms of violence and love in it are inappropriate for early childhood. Therefore, for the needs of character and multicultural education it is necessary to reconstruct folklore so that it can be used as a medium, source or means of learning for early childhood. There are many genes of research in multicultural education. However, the most important main objective is to conduct research and provide multicultural education for teachers so that they can develop it in their learning (Bennett, 2001).

This study aims to reveal: (1) the values of character and multicultural education contained in the folklore of North Sumatera; (2) the role of North Sumatera folklore which has been reconstructed as a medium for character building as well as a source of learning for multicultural education. The research design uses qualitative research methods with the ethnographic approach of Spradley (1980) by taking various informants, including early education teachers from kindergarten TK YPI. Amir Hamzah, traditional leaders who understand the folklore of North Sumatera, early age experts and fairytale village practitioners. Research techniques use interviews, observation, literature studies and documentation.

\section{Reconstruction North Sumatera Folklore For Early Chidhood}

Generally, almost all folklore contains mystical elements, love and violence. Surely this folklore content should not be introduced for early childhood. However, there is still much folklore that contains character and multicultural values that are good for early childhood. Therefore, it is necessary to attempt to reconstruct folklore so that it can be used as a medium or source of learning in early childhood. Early age is the most strategic stage of child development in forming good children's characteristics and multicultural education. In this age children can absorb learning from the people closest to the child's life such as from parents and teachers at school. When children are left to choose stories they like, they tend to choose stories that they already know and that reflect their culture. Therefore, according to Bieger (1996) it is very important for parents or teachers introduce various stories that reflect different cultures, themes and views. Through learning of North Sumatera folklore that has 
been reconstructed, it is hoped that it can shape the characteristics and multicultural education for children.

In the reconstruction of North Sumatra folklore, the value of character education is the focus on the importance of the introduction of diversity. Diversity in North Sumatra is a necessity faced in the social and cultural life of its citizens, especially at the kindergarten school YPI. Amir Hamzah Medan which carries the vision as a multicultural school.

In the story reconstruction process, the teacher must sort and determine the material with a multicultural perspective. The teacher first examines holistically the material will be used and delivered in the learning process. After the process of reviewing, selecting and defining the material, the teacher makes a learning plan as outlined in the Daily Learning Implementation Plan (RPHH). In this design, the teacher makes a theme about my country. In this theme, there are learning objectives, namely: children can correctly state about Indonesia in general, such as symbols, flags, traditional clothing. In addition to being able to speak, the teacher develops the material by directing children to contextual situations and conditions through folklore that have a multicultural value, especially in North Sumatra. These multicultural values also become a source of character education that is needed for early childhood in kindergarten.

\section{The Content Of Multicultural Valuea In North Sumatera Folklore}

In North Sumatra Province, there are indigenous groups including the Toba Batak, Mandailing or Angkola, Karo, Simalungun, Pakpak or Dairi, Malay and Nias. The seven ethnic groups are called host populations. Groups the ethnicity inhabits territories, which also represent their cultural identity. In addition, each ethnic group has cultural characteristics that become a marker of their identity. When these ethnic migrate from their original regions to the centre of Medan, they retain their identity. So far, every ethnic living in Medan city continues to express its cultural identity. This is what makes Medan City a multicultural city which, besides being a home for the host population, is also a meeting place for various migrant cultures from outside Sumatra, such as Java, Sunda, Aceh, Padang, etc.

With these conditions, the introduction of multicultural values is designed through folklore in early childhood in kindergarten education institutions. The content of multicultural values in the folklore chosen is about the story of Si Mardan and Sampuraga. The selection of this story is based on the review and analysis of the two folklore. The content of multicultural values in Si Mardan and Sampuraga's stories are some of the similarities found in narrative stories, while the two stories come from different cultural regions. Si Mardan is a folklore originating from Asahan which is a representation of the Malay ethnicity. The Sampuraga story comes from Padang Bolak Mandailing ethnic in North Sumatra.

Narratives of folklore that develop in society represent the culture of the speakers. Story motifs and characteristics found in folklore in one or more different stories in different places and cultures are the result of cultural contacts between storytellers (Ahimsa, 2006: 376). The stories of Si Mardan and Sampuraga have in common, both of them have the motive of 'wandering' by a boy. The motive of migrating to a number of ethnic North Sumatra, especially Toba and Mandailing is a cultural mission that must be carried out (Pelly, 2013). Another motive is the "struggle of a mother" that is responsible for raising and educating her child (Baiduri, 2014). Both motives are characteristic in both folklore originating from North Sumatra. 
The similarity of people's motifs found in North Sumatra can be analyzed based on adjacent spaces. Geographically, Asahan and Padang Bolak is still in the administrative area of North Sumatra. The proximity of this space allows for contact and distribution of culture and stories, of its people.

The folklore equation, if it is reviewed and analyzed based on Levis-Strauss structural theory, it will be found the lowest unit relationship (mytheme) story which gives a picture of the relationships that are arranged which can then be analyzed for similar motives. In its analysis of folklore, both legends and myths are influenced by linguistics. In a story that develops and is passed on orally, there is an order and repeatability (regularity). Furthermore, humans are genetically able to compose the symptoms faced (Ahimsa: 2006: 65-70). Based on the theory put forward by Levi Strauss, it can be found that the smallest unit relationship (miteme) is the form of the cultural mission of "wandering" and appreciation of the efforts and sacrifices and responsibilities of a mother to her child.

From the story of Si Mardan and Sampuraga, it was discovered how cultural values were internalized through the delivery of folklore that interpreted the cultural mission of each ethnic group. How the efforts of a boy who struggles to achieve a cultural mission through "wander" activities that become the motives and characteristics of stories appearing in the two stories show the occurrence of cultural contact in the community of folklore speakers. Therefore, these two stories show the structure of universal societal thinking through folklore that lives and develops in the speaking community, and it reflects universal character and multicultural value's education.

\section{Conclusions}

Based on the identification of research mapping on North Sumatra folklore, there are several contents values of character education and values of multicultural education. The content of character education values are moral, personality and social values. Moral, personality and social values are the basic capital of a person during living a life. The success or failure of a person in his life depends on these values. These values are the values of basic characteristics that should have been formed from an early age.

In addition to the important moral, personality and social values contained in North Sumatra folklore includes the values of multicultural education, which contain: (a) the value of diversity; (b) religious tolerance; (c) mutual respect; (d) solidarity and (e) able to work together in difference.

The folklore of North Sumatra, besides containing the values of character education, can also play a role as a learning media for multicultural education because each region in North Sumatra has a story about their respective regions that represent the history and culture of their society. Thus the folklore of North Sumatra can be used as a source and media that are very effective in growing and developing moral values rooted in the culture and personality of the Indonesian people. Efforts to introduce cultural diversities through North Sumatra folklore to children from an early age will shape children's understanding of cultural differences and diversity in North Sumatra. Multicultural education obtained through North Sumatra folklore can be a capital of local intelligence that serves as an anticipation of conflicts that may arise due to differences in each culture. Thus multicultural learning through folklore is expected to provide understanding to children from an early age, different cultures that exist in North 
Sumatra are not only seen through the perspective of cultural differences but universality of the thinking system of every culture that has character and multicultural education values.

\section{References}

[1] Ahimsa-Putra, Heddy Shri.: Strukturalisme Levi-Strauss: Mitos dan Karya Sastra (2006)

[2] Altman, T.: "Folklore and Education: A Selected Annotated Bibliography of Periodical Literature,". pp. 53-85 (1978)

[3] Baiduri, Ratih.: "The Meaning Dimensions of Work: Women Traders Toba-Batak (Inang-inang) in Medan, North Sumatera, Indonesia,”. Vol. 4, pp. 66-74. International Journal of Humanities and Social Science (2014)

[4] Bennett, Christine.: “Genres of Educational Research,”. pp. 171-217. Review of Educational Research Association (2001)

[5] Bieger, E. M.: "Promoting Multicultural Education through a Literature-Based Approach,". Vol. 49, pp. 308-312. The Reading Teacher (1996)

[6] Bulger, P.: "Politics, Principles, and Principals,". pp. 1320. Southern Folklore (1991)

[7] Hamer, L.: Folklore in Schools and Multicultural Education: Toward Institutionalizing Noninstitutional Knowledge,”. Vol. 113, pp. 44-69. The Journal of American Folklore (2000)

[8] Nusz, N.: Maritime Folk life in Lincoln Country: Student Magazine. (1994)

[9] Pelly, Usman.: Urbanisasi dan Adaptasi Peranan Misi Budaya Minangkabau dan Mandailing di Perkotaan. Medan. Unimed Press dan Casa Mesra Publisher (2013)

[10] Pryor, A., Bowman, P.: "Folklore and Education: A Short History of a Long Endeavour,". Vol. 129, pp. 436-458. The Journal of American Folklore (2016)

[11] Rosenberg, J.: Participant Observations. New York: Holt, Rinehart and Winston (1980)

[12] Spradley, J.: Participant Observations. New York: Holt, Rinehart and Winston (1980) 